\title{
EFFECTS OF PLASMAPHERESIS ON ALBUMIN POOLS IN RABBITS
}

\author{
By C. M. E. MATTHEWS*
}

(From the National Institute for Medical Research, London, England)

(Submitted for publication June 20, 1960; accepted October 27, 1960)

The normal regulation of intravascular plasma protein mass has not been fully investigated. It has long been known that plasma proteins rapidly return to normal concentrations after plasmapheresis, but the means by which this takes place has not been clearly demonstrated. In pathological states, such as nephrosis and hypercatabolic hypoproteinemia, where there may be a steady loss of plasma protein, some compensatory mechanism (see next paragraph) must be involved in cases in which the intravascular plasma proteins are in a steady state. Frequently the protein concentration alone is determined, so that it is not known whether changes are due to variations in plasma volume or in total intravascular protein mass. A steady state can only be said to exist when the plasma protein synthesized is equal to that catabolized, so that the total mass of protein, but not necessarily the concentration, is constant.

Disturbances of intravascular protein mass could be compensated for by $a$ ) change in synthesis rate, $b$ ) change in catabolic rate, $c$ ) net transfer of protein between extravascular and intravascular protein pools or $d$ ) a combination of several of these. There is also the possibility that the proportion of the different protein fractions is altered and that loss of one fraction is replaced by an increase of another fraction.

The purpose of this investigation was to obtain further evidence on this problem by removing protein by plasmapheresis and observing the effect on the catabolic rate, intravascular pool mass, concentration and volume, and on the sum of synthesis rate plus net transfer rate from extravascular to intravascular pool. Rabbits on a normal diet were used, and a single protein fraction, albumin, was considered.

$\mathrm{I}^{131}$-rabbit albumin was injected intravenously into rabbits, and plasma albumin specific activity (microcuries per gram), total body radioactivity

\footnotetext{
* Present address: Radiotherapeutic Research Unit, Hammersmith Hospital, London, England.
}

and urinary radioactivity were measured. It is assumed throughout that $\mathrm{I}^{131}$-albumin behaves as normal rabbit albumin $(1,2)$, that after catabolism the $I^{131}$ is rapidly excreted, and that there is rapid mixing in each separate protein pool so that within any one pool the specific activity is uniform.

A control period of ten days from the injection was allowed before starting plasmapheresis. The normal catabolic rate and pool masses were thus determined for each animal. Daily determinations of intravascular protein mass, concentration and volume were also made throughout each experiment in a control animal not subject to plasmapheresis.

Intravascular protein mass and plasma volume were determined by isotope dilution. Since the proportion of albumin to total plasma protein was found to be constant throughout the experiment, albumin masses could be calculated from total protein masses.

\section{METHODS}

\section{Theoretical.}

Extravascular pool. During the control period, the extravascular protein mass was determined by the equilibrium time method (3-5). In this method the ratio of extravascular to intravascular radioactivity, when extravascular activity is maximal, is taken to be the ratio of extravascular to intravascular protein. The assumptions made, in addition to those listed above, are that the pool masses and rates of exchange and catabolism are constant and that newly synthesized protein is discharged into, and catabolism occurs in, the intravascular pool or in a pool which is in rapid exchange with it. Extravascular activity is found by subtracting total intravascular activity (i.e., specific activity $\times$ mass) from total body activity.

During the plasmapheresis period the pools are probably not in a steady state so that this method is not valid.

Catabolic rate. The albumin catabolic rate is measured in grams per day by the method described by Campbell, Cuthbertson, Matthews and McFarlane (3). The 24hour urinary activity in microcuries is divided by the mean plasma albumin specific activity in microcuries per gram during the 24 hour period. This assumes that catabolism takes place in the intravascular pool or in some pool in rapid exchange with it (6). This method is valid even when the catabolic rate and pool mass are varying, since 
the only assumption involved is that the specific activity of the albumin catabolized is the same as that of the plasma albumin so that in any given period:

$\frac{\text { activity in urine }}{\text { mass of albumin catabolized }}=\frac{\text { activity in plasma }}{\text { mass of albumin in plasma }}$ and therefore

$$
\frac{\text { activity in urine }}{\text { plasma albumin specific activity }}=\begin{gathered}
\text { mass of albumin } \\
\text { catabolized. }
\end{gathered}
$$

Synthesis rate. Direct measurement of synthesis rate from incorporation of labeled amino acids into plasma proteins requires a knowledge of the immediate precursor specific activity, and this is very difficult to obtain (7). However, variations in synthesis rate give rise to variations in specific activity of labeled proteins. Catabolism alone will not alter the specific activity of the remaining labeled protein, but the extent to which the label is diluted will depend upon the rate of entry of new unlabeled molecules into the system of pools. Tarver (8) tabulates the effects of various changes in the system. 'However, in general, it cannot be assumed that the specific activities in the different pools are the same $(3,4)$, and exchange between the pools is therefore a complicating factor.

Consider a system of an intravascular and one extravascular protein pool with catabolism in the intravascular pool and newly synthesized protein entering this pool.

Following the notation of Rescigno (9) and Matthews (4), let subscript ${ }_{1}$ denote intravascular pool, and subscript 3 the extravascular pool.

$X_{1}, X_{3}=$ fraction of injected dose in pools 1,3 at time $t$.

$M_{1}, M_{3}=$ mass of protein in pools 1,3 .

$K_{01} \quad=$ protein synthesis rate as a fraction of $M_{1}$ per day.

$K_{12} \quad=$ protein catabolic rate as a fraction of $M_{1}$ per day.

$K_{T} \quad=$ net rate of transfer of protein from pool 3 to pool 1 as a fraction of $M_{1}$ per day.

$K_{13} \quad=$ fraction of protein in pool 1 entering pool 3 per day.

$K_{31} \quad=$ fraction of protein in pool 3 entering pool 1 per day.

Then: slope of intravascular specific activity curve (i.e., $0.693 /$ half-life in days)

$$
=\frac{-d\left(X_{1} / M_{1}\right) / d t}{X_{1} / M_{1}}=K_{01}+K_{31} \frac{M_{3}}{M_{1}}-K_{31} \frac{X_{3}}{X_{1}}=b .
$$

Slope of extravascular total activity curve

$$
\begin{aligned}
=\frac{-d X_{3} / d t}{X_{3}} & =K_{31}-K_{13} \frac{X_{1}}{X_{3}}=c \\
K_{01} & =b+\frac{X_{3}}{X_{1}} c+K_{13}-K_{31} \frac{M_{3}}{M_{1}} \\
K_{T} & =\frac{-d M_{3} / d t}{M_{1}}=K_{31} \frac{M_{3}}{M_{1}}-K_{13} \\
\therefore K_{01}+K_{T} & =b+\frac{X_{3}}{X_{1}} c .
\end{aligned}
$$

This equation is always valid even if all rates and masses are varying. For a steady state, $M_{3}$ is constant and $K_{T}$
$=0$, so that $K_{01}=b+\left(X_{3} / X_{1}\right) c$. Equation 1 was used to find the synthesis rate + transfer rate. Unfortunately it is not possible to distinguish between changes in synthesis rate and changes in transfer rate. It can be seen from Equation 1 that if $b, c$, and $X_{3} / X_{1}$ are constant, then $K_{01}$ $+K_{T}$ must be constant.

Also: slope of total body activity curve

$$
=\frac{-d\left(X_{1}+X_{3}\right) / d t}{X_{1}+X_{3}}=K_{12} \frac{X_{1}}{X_{1}+X_{3}}=d .
$$

$\therefore$ If $b=c=d$ (i.e., intravascular specific activity, extravascular total activity and total body activity curves are all parallel) then:

$$
\begin{aligned}
K_{01}+K_{31} \frac{M_{3}}{M_{1}}-K_{31} \frac{X_{3}}{X_{1}}=K_{31}- & K_{13} \frac{X_{1}}{X_{3}} \\
& =K_{12} \frac{X_{1}}{X_{1}+X_{3}} .
\end{aligned}
$$

Fractional rate of change of intravascular pool mass

$$
=\frac{d M_{1} / d t}{M_{1}}=K_{01}-K_{12}-K_{13}+K_{31} \frac{M_{3}}{M_{1}}
$$

Combining Equations 2 and 3, it can easily be shown that;

$$
\frac{d M_{1} / d t}{M_{1}}=0
$$

Therefore, if intravascular specific activity, extravascular total activity and total body activity curves are parallel, the mean intravascular protein mass must be constant.

\section{Experimental}

Animals. Male Sandylop rabbits bred at the National Institute for Medical Research were used; they received pelleted diet SG1 (10). The drinking water contained 0.005 per cent sodium iodide and 0.47 per cent sodium chloride from 3 days before the first injection until the end of the experiment, in order to increase the rate of iodide excretion.

Preparation of rabbit albumin. Rabbit albumin was kindly prepared by Dr. S. Cohen from $4 \mathrm{ml}$ rabbit serum by electrophoresis, according to Porath (11), on a column of treated cellulose $3 \mathrm{~cm}$ in diameter and $45 \mathrm{~cm}$ long, using a current of 22 ma for 46 hours, and a borate phosphate buffer ( $\mathrm{pH} 8.60, \mu=0.05$ ).

Iodination. Iodination was carried out by the iodine monochloride method as described by McFarlane (12), after which free iodine was removed by passage through anion exchange columns of Deacidite (Permutit \& Co., London).

Injection and samples. The iodinated albumin or plasma, in a volume of less than $2 \mathrm{ml}$, was injected into the marginal ear vein, and a sample of blood was withdrawn about 5 minutes later from the opposite marginal ear vein. The activity to be injected and the syringe washings were counted and the injected dose obtained by difference.

Urine was collected every 24 hours, before I ${ }^{132}$ injection, the cages being washed down with $0.05 \mathrm{~N}$ sodium hydroxide. The volume of urine and washings was measured and a 3 $\mathrm{ml}$ aliquot taken for counting. 
TABLE I

Fall in intravascular specific activity after injection of labeled protein, before and after plasmapheresis

\begin{tabular}{cccc}
\hline \hline & \multicolumn{3}{c}{ Relative specific activity } \\
\cline { 2 - 4 } $\begin{array}{c}\text { Time } \\
\text { from } \\
\text { injection }\end{array}$ & $\begin{array}{c}\text { Before } \\
\text { plasmaph. }\end{array}$ & $\begin{array}{c}2 \mathrm{hrs} \\
\text { after } \\
\text { plasmaph. }\end{array}$ & $\begin{array}{c}4.3 \mathrm{hrs} \\
\text { after } \\
\text { plasmaph. }\end{array}$ \\
\hline $5 \mathrm{~min}$ & 100 & 100 & 100 \\
$1.2 \mathrm{hr}$ & 90.1 & 88.0 & \\
$2.0 \mathrm{hr}$ & 78.9 & & 82.5 \\
$2.2 \mathrm{hr}$ & & & \\
$2.8 \mathrm{hr}$ & & & \\
\hline
\end{tabular}

Intravascular protein mass and plasma volume. Intravascular protein mass and volume were obtained by isotope dilution, initially from the injection of $\mathrm{I}^{131}$-albumin, and subsequently throughout the experiment by injection of $I^{132}$-rabbit plasma. When $I^{132}$-plasma was injected, a blood sample was taken a few minutes before the injection to determine the $\mathrm{I}^{131}$ activity in the blood at this time. Another sample was then taken about 5 minutes after injection; the injected dose divided by the $\mathrm{I}^{132}$ activity per milliliter of plasma and per gram of protein gave the plasma volume and intravascular total protein, respectively. Since the fall in specific activity after injection is slow, it was considered sufficient to take a single sample for specific activity measurement (see Table I).

TABLE II

Nonprotein-bound radioactivity before and during plasmapheresis

\begin{tabular}{|c|c|c|}
\hline & Time & $\begin{array}{c}\text { Activity in TCA } \\
\text { supernatant }\end{array}$ \\
\hline \multirow[t]{8}{*}{ Plasma } & $\begin{array}{c}\text { hrs } \\
0.083(5 \mathrm{~min}) \\
17.7 \\
26 \\
40 \\
50 \\
64\end{array}$ & $\begin{array}{c}\% \text { of total } \\
0.69 \\
1.25 \\
1.07 \\
0.87 \\
0.79 \\
1.11\end{array}$ \\
\hline & $\begin{array}{l}68 \\
89\end{array}$ & $\begin{array}{l}1.97 \\
0.92\end{array}$ \\
\hline & $\begin{array}{r}91 \\
113\end{array}$ & $\begin{array}{l}1.29 \\
0.79 \\
*\end{array}$ \\
\hline & $\begin{array}{l}116 \\
137 \\
185\end{array}$ & $\begin{array}{c}1.40 \\
1.03 \\
1.06 \\
*\end{array}$ \\
\hline & $\begin{array}{l}187 \\
209\end{array}$ & $\begin{array}{l}1.44 \\
0.92 \\
*\end{array}$ \\
\hline & 212 & 1.28 \\
\hline & 233 & 0.81 \\
\hline & $\begin{array}{l}235 \\
257\end{array}$ & $\begin{array}{c}0.94 \\
1.04 \\
*\end{array}$ \\
\hline Lymph & 261 & $>1.1$ and $<2.1$ \\
\hline
\end{tabular}

* Plasmapheresis.
Measurement of radioactivity. Urine samples and dilutions of plasma samples were counted in a well-type scintillation counter. Since urine samples were collected in the morning before $\mathrm{I}^{132}$ injection, the $\mathrm{I}^{132}$ injected the day before had decayed to a negligible amount compared with the I $^{131}$ activity.

Plasma samples containing both $\mathrm{I}^{132}$ and $\mathrm{I}^{131}$ activity were counted as soon as possible and then recounted the following day to obtain the $\mathrm{I}^{131}$ activity. By subtracting the $I^{131}$ activity (corrected for decay) from the first count, the $I^{132}$ activity at this time was obtained.

The total body activity was measured in a ring counter of eight Geiger tubes (4). The $I^{131}$ and $I^{132}$ activities for injection and the activity in the washings were also measured in the ring counter.

Iodine-132. $\mathrm{Te}^{132}$ on an alumina column was obtained from A.E.R.E., ${ }^{1}$ Harwell. $\quad I^{132}$ was eluted daily by pouring $0.01 \mathrm{M}$ ammonia through the column. The eluent was evaporated down to a small volume which was used for iodination. A sample of each eluent was counted in the ring counter and recounted the next day to check the proportion of $\mathrm{I}^{131}$ activity. This was always less than 0.5 per cent.

Protein determinations. Total protein was determined by the biuret method of Gornall, Bardawill and David (13). The proportion of albumin to total protein was determined by finding the ratio of $\mathrm{I}^{131}$-albumin to $\mathrm{I}^{131}$-total protein

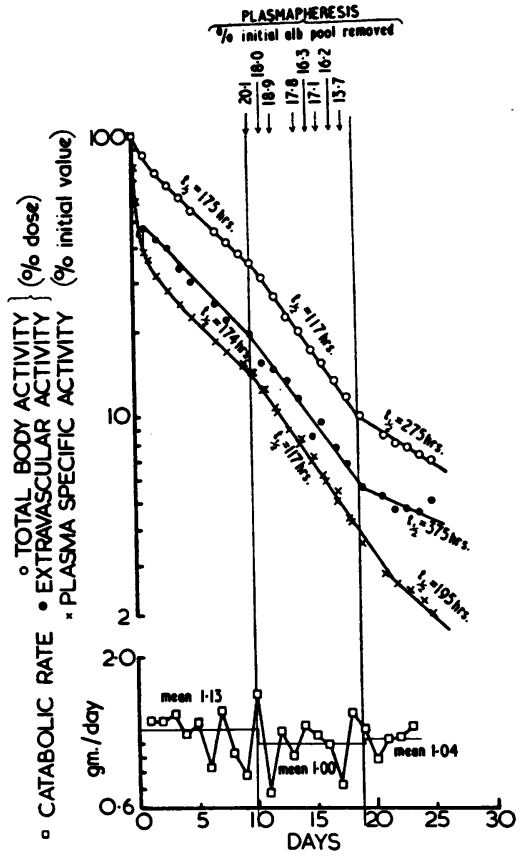

Fig. 1. Experiment C0, Rabbit A. Total body activity, $\bigcirc$; total extravascular activity, $\bigcirc$; plasma albumin specific activity as per cent of value 5 minutes after injection, $X$; albumin catabolic rate, $\square$ before, during and after plasmapheresis.

\footnotetext{
${ }^{1}$ Atomic Energy Research Establishment.
} 


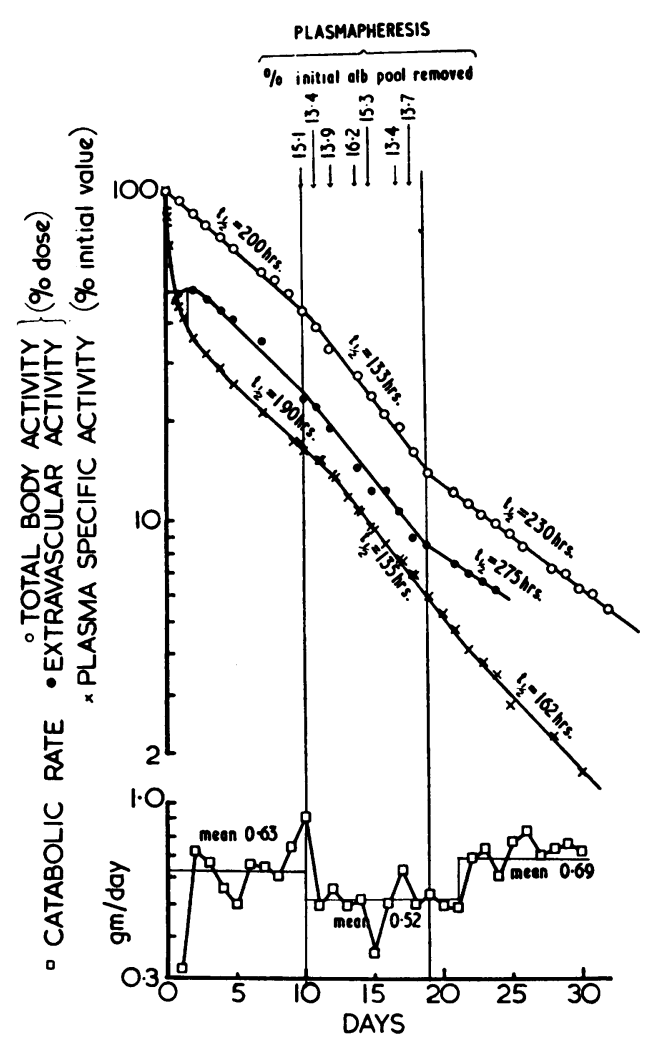

Fig. 2. Experiment C1, Rabbit B. Total body activity, $\bigcirc$; total extravascular activity, $\bigcirc$; plasma albumin specific activity as per cent of value 5 minutes after injection, $\times$; albumin catabolic rate, $\square$ before, during and after plasmapheresis.

specific activities, since only the albumin was labeled with I $^{131}$. Albumin specific activities were determined as follows. The globulins were precipitated with 1 per cent trichloroacetic acid in alcohol as described by Debro, Tarver and Korner (14). The albumin in the supernatant was then reprecipitated with an equal volume of ether and the precipitate dissolved in $2 \mathrm{ml}$ saline. This was then counted and the albumin determined by the biuret method, as for the plasma samples.

Plasmapheresis. Blood was withdrawn from the marginal ear vein into a sterile tube containing about $500 \mathrm{IU}$ of heparin. After centrifugation, the supernatant plasma was removed, and the red cells and trapped plasma were diluted with about 5 to $10 \mathrm{ml}$ of saline and reinjected into the marginal ear vein. The interval between bleeding and injection of red cells was approximately 40 minutes. In each experiment plasmapheresis was continued daily for 9 days except on Day 4 in Experiment C0 and on Days 4 and 7 in Experiment $\mathrm{C} 1$.

Nonprotein-bound activity. This was determined by adding 1 drop 10 per cent sodium iodide, $0.5 \mathrm{ml} 10$ per cent albumin solution and one-third of the volume of 30 per cent trichloroacetic acid. The percentage of radioactivity in the supernatant was taken as the percentage of non- protein-bound activity. The results for one rabbit are shown in Table II.

\section{RESULTS}

The complete experiments described were carried out with plasmapheresis in four rabbits and in two control rabbits. There were also incomplete experiments in three other rabbits in which only one isotope was used. The results were all similar.

Figures 1 and 2 show the total body activity, extravascular activity, and plasma specific activity curves and also the catabolic rates for two of the rabbits. Plasma specific activity curves are seen to be approximately parallel to total body activity curves before and during the period in which daily plasmapheresis was carried out, which implies that the mean intravascular protein mass is constant during this period (see Equation 3 et seq.). After this "plasmapheresis period" the slope of the plasma specific curve is not constant but is greater than that of the total body activity curve. The changes in plasma specific activity slope sometimes lag behind the changes in total body activity slope.

The catabolic rate falls slightly during the plasmapheresis period and rises again afterward. Figure 3 shows the changes in intravascular specific activity after plasmapheresis in greater detail.

Figure 4 shows the variations in intravascular protein mass, concentration and volume for one of these rabbits. There is a gradual fall in mean concentration during the plasmapheresis period, with a gradual return to normal afterward. This mainly reflects an increase in plasma volume as the total protein mass is approximately constant. (The mean intravascular protein mass during the

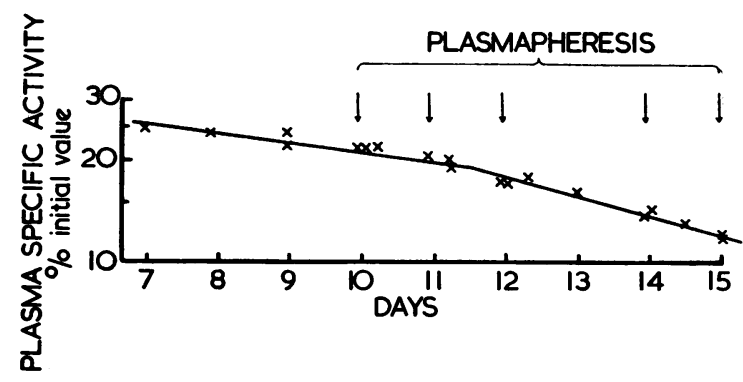

Fig. 3. Experiment C0, Rabbit B. Plasma albumin specific activity as per cent of value 5 minutes after injection, before and during plasmapheresis. 


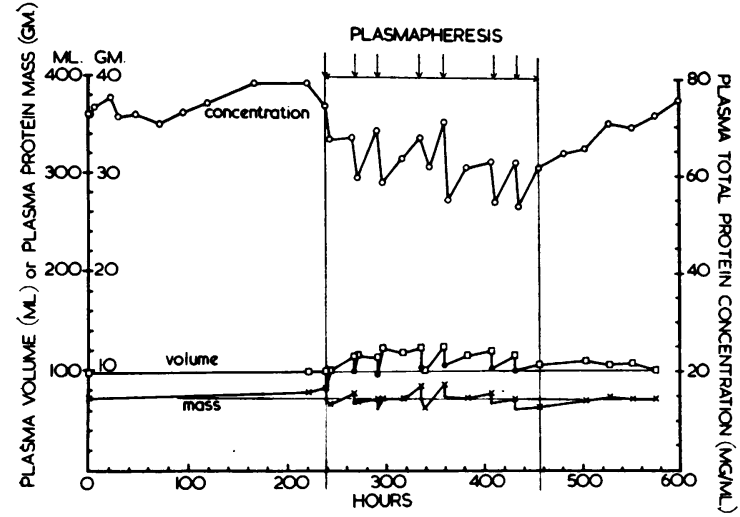

Fig. 4. Experiment C1, RABbit B. Intravascular total protein mass, $X$; intravascular total protein concentration, $\bigcirc$; plasma volume, $\square$ before, during and after plasmapheresis. Calculated protein masses after plasmapheresis, ; these are the values before plasmapheresis minus the protein withdrawn.

plasmapheresis period is actually 6.5 per cent less than in the control period in this rabbit. This is probably significant, $\mathrm{p} \sim 2$ per cent). The concentration falls sharply immediately after plasmapheresis and later rises. Figure 5 shows the variations in intravascular protein mass, concentration and volume for a control rabbit with no plasmapheresis.

Table III shows the pool masses and the changes in catabolic rate, and synthesis and transfer rate calculated as described above. The total compensatory changes agree quite well with the amount of albumin withdrawn. This must be so if the

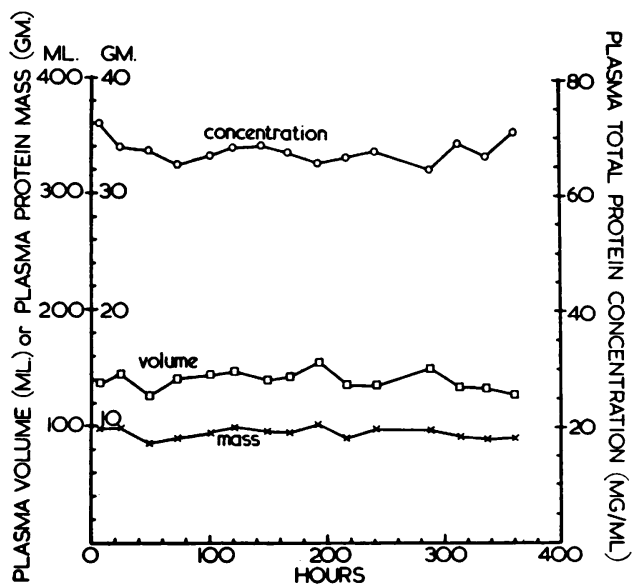

Fig. 5. Experiment C1, Rabbit D, control. Intravascular total protein mass, $X$; intravascular total protein concentration, $\bigcirc$; plasma volume, $\square$

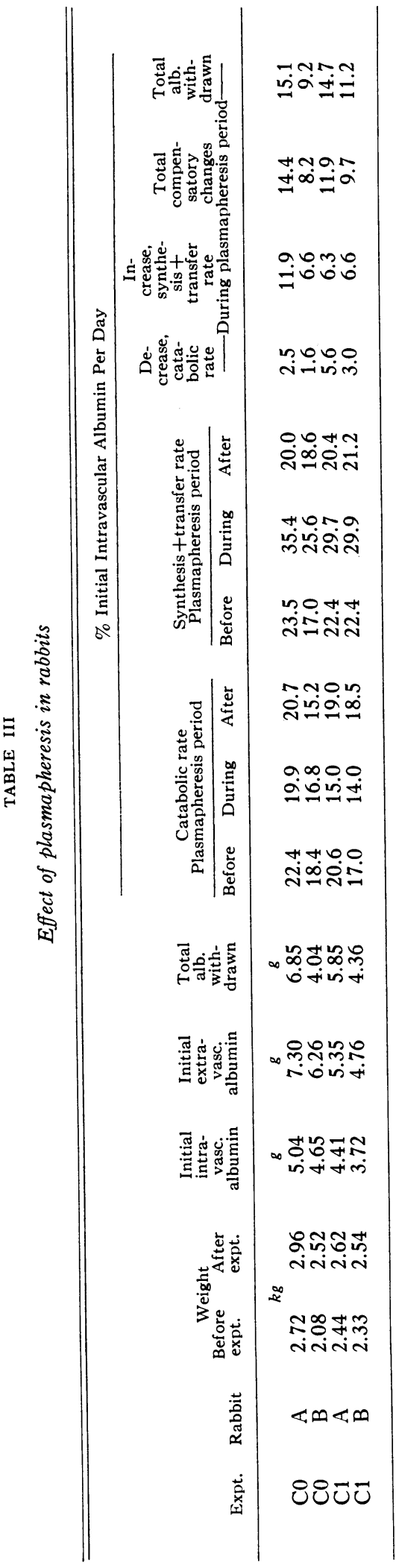


TABLE IV

Intravascular albumin as per cent total intravascular protein *

\begin{tabular}{|c|c|c|c|c|c|c|c|c|}
\hline \multirow{2}{*}{\begin{tabular}{l}
\multicolumn{1}{c}{ Experiment } \\
$\begin{array}{l}\text { Before } \\
\text { plasmapheresis }\end{array}$
\end{tabular}} & \multicolumn{2}{|c|}{$\mathrm{CO}, \mathrm{A}$} & \multicolumn{2}{|c|}{$\mathrm{CO}, \mathrm{B}$} & \multicolumn{2}{|c|}{$\mathrm{C} 1, \mathrm{~A}$} & \multicolumn{2}{|c|}{$\mathrm{C} 1, \mathrm{~B}$} \\
\hline & $\begin{array}{l}240 \\
\text { Mean }\end{array}$ & $\begin{array}{l}\% \text { alb. } \\
64.6\end{array}$ & $\begin{array}{r}\text { hrs } \\
0\end{array}$ & $\begin{array}{c}\% \text { alb. } \\
54.4 \\
58.5\end{array}$ & $\begin{array}{c}h r s \\
0 \\
1.3 \\
22.5 \\
47 \\
95 \\
167 \\
239\end{array}$ & $\begin{array}{c}\% \text { alb. } \\
53.4 \\
56.9 \\
57.8 \\
54.4 \\
60.7 \\
58.5 \\
58.0 \\
57.1\end{array}$ & $\begin{array}{c}h r s \\
0 \\
1.3 \\
22.5 \\
47 \\
95 \\
167 \\
239\end{array}$ & $\begin{array}{c}\% \text { alb. } \\
50.9 \\
51.1 \\
61.0 \\
47.0 \\
55.5 \\
51.6 \\
49.6 \\
52.4\end{array}$ \\
\hline $\begin{array}{l}\text { During } \\
\text { plasmapheresis }\end{array}$ & $\begin{array}{c}457 \\
\text { Mean }\end{array}$ & $\begin{array}{l}52.1 \\
59.4\end{array}$ & $\begin{array}{l}288 \\
364\end{array}$ & $\begin{array}{l}59.5 \\
56.9\end{array}$ & $\begin{array}{l}267 \\
291 \\
339 \\
435 \\
456\end{array}$ & $\begin{array}{l}57.1 \\
58.5 \\
60.5 \\
62.0 \\
48.4 \\
57.3\end{array}$ & $\begin{array}{l}267 \\
291 \\
339 \\
435 \\
456\end{array}$ & $\begin{array}{l}52.4 \\
48.0 \\
50.5 \\
55.9 \\
52.4 \\
51.8\end{array}$ \\
\hline $\begin{array}{l}\text { After } \\
\text { plasmapheresis }\end{array}$ & 552 & 62.5 & 576 & 54.1 & 528 & 52.5 & 528 & 53.0 \\
\hline
\end{tabular}

* Ratio of total protein specific activity to albumin specific activity.

assumptions made are correct, and confirms that the intravascular albumin mass is approximately constant. About 70 to 80 per cent of the withdrawal is compensated for by an increase in the synthesis plus transfer rate and the remainder by a decrease in the catabolic rate. The greatest decrease in the catabolic rate is 27 per cent of the initial value. Table IV shows the ratio of total protein to albumin specific activity. Since this ratio does not change significantly throughout the experiment the albumin pool must be a constant fraction of the total protein pool.

Since the total intravascular albumin mass is constant, changes in percentage of catabolic and synthesis rates are proportional to changes in absolute rates (i.e., in milligrams per day).

\section{DISCUSSION}

Removal of intravascular protein by plasmapheresis appears to be mainly compensated for either by a change in the synthesis rate or by transfer of protein from extravascular to intravascular pool, or both. These possibilities cannot be distinguished since only the synthesis plus transfer rate can be determined. The change in catabolic rate is comparatively small. The plasma volume increases after each bleed and the concentration falls. Later, concentration rises, so that the protein is evidently replaced more slowly than is the water. An increase in plasma volume after plasmapheresis was also observed by Whipple, Miller and Robscheit-Robbins (15), and by Rodionov and co-workers (16).

If the synthesis rate remains constant, the extravascular pool must be greatly reduced. For example, for Rabbit A in Experiment C0:

(albumin withdrawal rate - decrease in catabolic rate) $\times 9$ days $=78$ per cent extravascular pool.

I.e., this pool would have decreased to 22 per cent of the initial value. This seems very unlikely. The concentration of total protein for this rabbit fell to about 78 per cent of the original value, so that unless the extravascular volume was reduced, the concentration gradient between intra- and extravascular pools would have to be 3.5 times greater than normal. It therefore seems very probable that the synthesis rate is increased during plasmapheresis.

The constant ratio of extravascular to intravascular activity does not necessarily indicate a constant ratio of protein masses, since the extravascular specific activity is not known. Similarly after plasmapheresis, the increasing extravascular to intravascular activity ratio is not necessarily due to an increase in the protein ratio, although this remains the simplest explanation. If there is a net transfer of protein from intravascular to extravascular pool after the plasmapheresis period, the transfer rate $K_{T}$ will be negative, and the synthesis rate will be greater than the values cal- 
culated for synthesis plus transfer rate (see Table III). Thus, by this explanation the synthesis rate would remain higher than normal after the plasmapheresis period is over and the extra protein produced would increase the extravascular pool mass.

If extravascular mass remains constant throughout, i.e., if the transfer rate is zero, then the synthesis rate must have returned to normal after the plasmapheresis period (see Table III). The system would then be in equilibrium, except that the catabolic rate has not quite returned to normal in most cases. However, the small difference between synthesis and catabolic rate seems hardly great enough to account for the difference in extravascular activity and intravascular specific activity slopes so that there was probably some change in extravascular protein mass. In the steady state the slopes should, of course, be equal (8).

The most likely hypothesis, therefore, seems to be that during the plasmapheresis period the intravascular pool mass is kept constant mainly by both net transfer of protein from the extravascular pool and increased synthesis, and that after the plasmapheresis period the synthesis rate remains high for a time so that the extravascular pool gradually returns to normal. This would be in agreement with the results of some other workers. Wasserman, Joseph and Mayerson (17) conclude from plasmapheresis and infusion experiments in dogs that albumin is first replaced from the extravascular pool and later by increased synthesis. Rodionov and associates (16) reach the same conclusions from plasmapheresis experiments in dogs with and without liver denervation, but they also find a large increase in globulins after bleeding. Reeve and Roberts (18) find a constant catabolic rate of albumin in grams per day per unit body weight for normal rabbits, independent of plasma albumin concentration. They conclude from this that it is likely that albumin mass is maintained by regulation of the synthesis rate.

Experiments in which plasma proteins are depleted by means of a low protein diet (19-21) may not be directly comparable with plasmapheresis experiments, since the depletion is produced in a different way.

It is remarkable how little the mean intravascular pool mass deviates from the normal value considering the large amount of protein withdrawn. A sensitive mechanism must exist for altering the transfer rate plus synthesis rate to compensate for the protein removed. Furthermore, the sum of the transfer rate plus synthesis rate must be constant during the plasmapheresis period (see Equation 3 et seq.). It seems likely that the transfer rate will be reduced as the extravascular pool becomes smaller, so that the synthesis rate must be increasing by just the required amount to balance this effect. This suggests that synthesis rate depends upon the extravascular protein mass or concentration. Thus the intravascular pool would be maintained at the expense of the extravascular pool, and the reduction of this pool would stimulate increased synthesis.

\section{SUMMARY}

The effects on the albumin pools of a period of daily plasmapheresis in rabbits are as follows.

1. Intravascular albumin mass fluctuates about a mean value which is approximately constant throughout the experiment.

2. Plasma volume increases during the plasmapheresis period and albumin concentration falls. After the plasmapheresis period, volume and concentration slowly return to normal.

3. Intravascular albumin is a constant fraction of intravascular total protein throughout the experiment.

4. During the plasmapheresis period, intravascular specific activity and total body activity curves are parallel.

5. Approximately 70 to 80 per cent of the albumin removed is replaced by either net transfer of protein from extravascular to intravascular pool or by increased synthesis, or both. The data do not distinguish between these possibilities.

6 . Twenty to thirty per cent of the albumin removed is compensated for by a reduction in the catabolic rate.

\section{ACKNOWLEDGMENTS}

I would like to thank Dr. S. Cohen and Dr. T. Freeman for many helpful discussions and suggestions, and Miss J. Willcox for skilled technical assistance.

\section{REFERENCES}

1. Cohen, S., Holloway, R. C., Matthews, C., and McFarlane, A. S. Distribution and elimination of ${ }^{131} \mathrm{I}-$ and ${ }^{14} \mathrm{C}$-labelled plasma proteins in the rabbit. Biochem. J. 1955, 62, 143. 
2. Freeman, T., Matthews, C. M. E., McFarlane, A. S., Bennhold, A., and Kallee, E. Albumin labelled with iodine-131 in an analbuminaemic subject. Nature (Lond.) 1959, 183, 606.

3. Campbell, R. M., Cuthbertson, D. P., Matthews, C. M., and McFarlane, A. S. Behaviour of ${ }^{14} \mathrm{C}$ and ${ }^{131}$ I-labelled plasma proteins in the rat. Int. J. appl. Radiat. 1956, 1, 66.

4. Matthews, C. M. E. The theory of tracer experiments with ${ }^{131}$ I-labelled plasma proteins. Phys. in Med. Biol. 1957, 2, 36.

5. Freeman, T., and Matthews, C. M. E. Analysis of the behaviour of ${ }^{181} \mathrm{I}$ albumin in the normal subject and nephrotic patient. Strahlentherapie 1958, 38, 283 and 306.

6. McFarlane, A. S. The behaviour of $\mathrm{I}^{131}$-labeled plasma proteins in vivo. Ann. N. Y. Acad. Sci. 1957, 70, 19.

7. McFarlane, A. S. Use of labeled plasma proteins in the study of nutritional problems. Progr. Biophys. 1957, 7, 116.

8. Tarver, H. The Proteins. New York, Academic Press, 1954, p. 1199.

9. Rescigno, A. A contribution to the theory of tracer methods. Part II. Biochim. biophys. Acta 1956, $21,111$.

10. Short, D. J., and Gammage, L. A new pelleted diet for rabbits and guinea pigs. J. Anim. Tech. Ass. 1959, 9, 62.

11. Porath, J. Purification of bacitracin polypeptides by charcoal chromatography and zone electrophoresis. Acta chem. scand. 1954, 8, 1813.

12. McFarlane, A. S. Efficient trace-labelling of proteins with iodine. Nature (Lond.) 1958, 182, 53.
13. Gornall, A. C., Bardawill, C. J., and David, M. M. Determination of serum proteins by means of the biuret reaction. J. biol. Chem. 1949, 177, 751.

14. Debro, J. R., Tarver, H., and Korner, A. The determination of serum albumin and globulin by a new method. J. Lab. clin. Med. 1957, 50, 728.

15. Whipple, G. H., Miller, L. L., and Robscheit-Robbins, F. S. Raiding of body tissue protein to form plasma protein and haemoglobin. What is premortal rise of urinary nitrogen? J. exp. Med. 1947, 85, 277.

16. Rodionov, V. M., Uspenskaya, V. D., Zamyatkina, O. G., Grunt, T. P., and Polyakova, V. P. Reconstitution of plasma proteins in dogs following severe bleeding. Vop. med. Him. 1957, 3, 255. (Chem. Abstr. 1959, 53, 5461.)

17. Wasserman, K., Joseph, J. D., and Mayerson, H. S. Kinetics of vascular and extravascular protein exchange in unbled and bled dogs. Amer. J. Physiol. 1956, 184, 175.

18. Reeve, E. B., and Roberts, J. E. The catabolism of plasma albumin in the rabbit; its rate and regulation. J. gen. Physiol. 1959, 43, 445.

19. Yuile, C. L., Lucas, F. V., Neubecker, R. D., Cochrane, C. G., and Whipple, G. H. Depletion of reserve protein from extravascular extracellular fluid. $\mathrm{C}^{14}$ labelling of plasma proteins in dogs after plasmapheresis. J. exp. Med. 1959, 109, 165.

20. Garrow, J. S. The effect of protein depletion on the distribution of protein synthesis in the dog. $\mathrm{J}$. clin. Invest. 1959, 38, 1241.

21. Gitlin, D., Cravioto, J., Frenk, S., Montano, E. L., Galvan, R. R., Gomez, F., and Janeway, C. A. A1bumin metabolism in children with protein malnutrition. J. clin. Invest. 1958, 37, 682. 